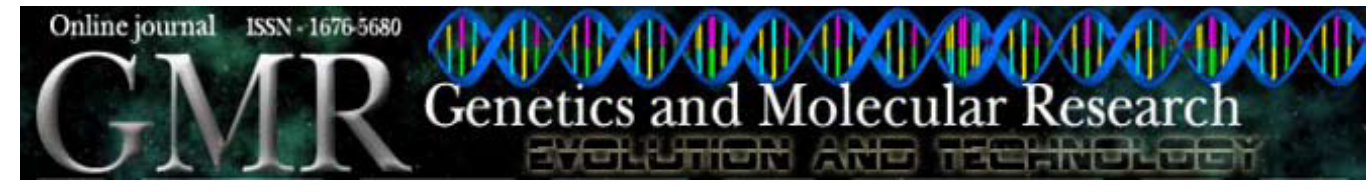

\title{
Sequential hygienic behavior in Carniolan honey bees (Apis mellifera carnica)
}

\author{
K.P. Gramacho ${ }^{1}$ and L.S. Gonçalves ${ }^{2}$ \\ ${ }^{1}$ Curso de Ciências Biológicas, \\ Faculdade de Tecnologia e Ciências, Salvador, BA, Brasil \\ ${ }^{2}$ Departamento de Biologia, Faculdade de Filosofia, \\ Ciências e Letras de Ribeirão Preto, Universidade de São Paulo, \\ Ribeirão Preto, SP, Brasil \\ Corresponding author: K.P. Gramacho \\ E-mail: gramacho.ssa@ftc.br; katholausa@hotmail.com
}

Genet. Mol. Res. 8 (2): 655-663 (2009)

Received December 12, 2008

Accepted January 26, 2009

Published June 9, 2009

\begin{abstract}
We examined the sequence, order or steps of hygienic behavior (HB) from pin-killed pupae until the removal of them by the bees. We conducted our study with four colonies of Apis mellifera carnica in Germany and made four repetitions. The pin-killing method was used for evaluation of the HB of bees. The data were collected every $2 \mathrm{~h}$ after perforation, totaling 13 observations. Additionally, for one hygienic colony and another non-hygienic colony, individual analyses of each dead pupa were made at every observation, including all details, steps or sequences of HB. The bees recognize the cells containing dead pupae within $2 \mathrm{~h}$ after perforation, initially making a hole in the capping, which is the beginning of HB. Uncapping of the dead brood cell reached maximum values from 4 to $6 \mathrm{~h}$ after perforation; after $24 \mathrm{~h}$, practically all cells were already uncapped. Another variable, called brood partially removed, was analyzed $4 \mathrm{~h}$ after perforation, after the cells had been perforated, which involved uncapping, followed by partial or total removal of the brood. Maximum values of brood partially removed were found 10 $\mathrm{h}$ after perforation, though such cells could be found up to $48 \mathrm{~h}$ after perforation. The most frequent sequence of events in both colonies
\end{abstract}


was: capped cell $\rightarrow$ punctured cell $\rightarrow$ brood partially removed $\rightarrow$ empty cell. A new model of three pairs of recessive genes (uncapping $\mathrm{u} 1, \mathrm{u} 2$ and remover $\mathrm{r}$ ) was proposed in order to explain the genetic control of the HB in Apis mellifera. We recommend evaluating HB $24 \mathrm{~h}$ after perforation and using a correction factor to compensate for control removal levels. We found a series of details of HB, which allow a study of how various factors may affect the sequence of the activities involved in HB and investigation of the genetics that controls this process.

Key words: Hygienic behavior; Honey bees; Apis mellifera carnica; Sequences of hygienic behavior; Carniolan bees

\section{INTRODUCTION}

Hygienic behavior (HB) in Apis mellifera consists of the removal of sick, injured or dead brood from the colony by the workers (Rothenbuhler, 1964a,b; Gonçalves and Kerr, 1970; Message, 1979). This behavior is also defined as the removal of any strange material found by the workers inside the colony (Message, 1979). Moretto (1993) introduced the concept of hygienic behavior for the removal of brood mites from infested brood cells. Hygienic behavior is very important for the population dynamics of bees because it can avoid or hinder the development of brood diseases, being considered the primary defense of honey bees against American foulbrood, European foulbrood, chalkbrood, and Varroa infestations (Park et al., 1937; Woodrow and Holst, 1942; Rothenbuhler, 1964a,b; Gilliam et al., 1983; Spivak and Reuter, 1998). According to Rothenbuhler (1964 a,b) HB is genetically controlled by two pairs of recessive genes $(\mathrm{u}=$ uncapping and $\mathrm{r}=$ remover), which when they are homozygous allow bees to identify sick, killed or infested brood inside capped cells and then to uncap the cell and remove the brood. It is known that the HB is highly variable and is influenced by climatic conditions such as humidity and temperature, as well as the colony conditions (Message, 1979; Message and Gonçalves, 1984a,b; Gramacho and Gonçalves, 1996; Gramacho et al., 1998). Message (1979) found that HB involves three steps instead of two: 1) perforation, in which the bees make one or two small holes in the capped cell, 2) uncapping and 3) removal of the brood. However, Milne Jr. (1985) analyzed this behavior and indicated that perforation is related to uncapping; he concluded that HB is controlled by just two pairs of genes. Moritz (1988) made a reevaluation of the two-locus model for hygienic behavior in honey bees and indicated that the genetic mechanism could be more complex. He proposed a three-loci model, in which one pair of genes ( $u=$ uncapping) in homozygosity is responsible for uncapping of the cell and two pairs ( $\mathrm{r} 1$ and $\mathrm{r} 2$ = removers) are responsible for removal of the brood. However, this hypothesis has not been proven. Kefuss et al. (1996) postulated that HB is controlled by 20 to 30 genes. However, they consider that this behavior needs to be better studied. Despite the unquestionable scientific contribution of Rothenbuhler $(1964 a, b)$ and of others who have also examined HB, it still is not clear how many genes are involved, nor is it known what behavioral steps are involved and what factors influence this complex process. Normally, experiments done on HB only present the final results of the 
removal of brood in order to classify the colony as hygienic or not; they do not examine the steps involved in this behavior. We therefore decided to study the steps or sequences of hygienic behavior.

\section{MATERIAL AND METHODS}

This experiment was done at the Bee Institute (Institut fur Bienenkunde) of the University of Hohenheim, Stuttgart, Germany. Four colonies of Carniolan bees (Apis mellifera carnica) were used, with four repetitions at intervals of 15 to 20 days, from June to August 1996.

Hygienic behavior was evaluated by the pin-killing method according to Newton and Ostasiewski (1986), modified by Gramacho and Gonçalves (1994). Combs containing capped worker brood cells aged 10 to 14 days old were taken from each colony. In one side of the comb two areas $(6 \mathrm{~cm} \times 6 \mathrm{~cm})$ that included 100 capped worker brood cells each were delimited. One of these areas was perforated with a number 1 insect pin and the other was left undisturbed, as a control. The combs were observed 13 times, until 48 $\mathrm{h}$ after brood cell perforation, as follows at $0,2,4,6,8,10,24,26,28,30,32,34$, and 48 h. Observations were made of each of the following characters: i) number of capped cells (CC); ii) number of empty cells (EC); iii) number of punctured cells (PC); iv) number of uncapped cells (UC); v) number of cells with brood partially removed (BPR) interpreted as cannibalism, and vi) association of punctured cell (PC) + uncapped cell (UC) + brood partially removed (BPR). The data were collected in two series. Series 1: data on the capacity of brood removal by the workers of four colonies; series 2: monitoring of individual brood cells in a hygienic colony and in a non-hygienic colony. In series 2 , the status of each cell was individually monitored and registered at each observation. One thousand and three hundred observations were registered for each colony (100 brood cells observed 13 times, until $48 \mathrm{~h}$ after perforation). After monitoring the status of each cell, the frequency of events in each cell during the $48 \mathrm{~h}$ of observation was recorded. The frequencies of the various sequences of the characters were calculated for the hygienic colony and the non-hygienic colony.

\section{RESULTS}

\section{Series 1. Capacity of brood removal by the workers}

Great variability in the HB of the four colonies was observed (Table 1, Figure 1). Twenty-four hours after perforation most of the killed or injured brood was removed. The Z-factor (correction factor) varied from 1 to $4 \%$; this corresponds to natural removal rates (without perforation). It was observed that the frequency of character 6 (PC + UC + BPR) was inversely proportional to that of HB. Two hours after perforation, workers had already detected the dead or injured brood and started to make small holes in the cell capping. The highest frequency of punctured cell was found at $4 \mathrm{~h}$ after perforation; it gradually decreased until $24 \mathrm{~h}$, when it reached $0 \%$. Two hours after perforation all colonies already had some uncapped cells; this reached the highest frequency at 4 to $6 \mathrm{~h}$ after perforation; $24 \mathrm{~h}$ after perforation most of the cells were already uncapped. The character 
brood partially removed was evident about $4 \mathrm{~h}$ after perforation; normally it occurred after the cells had been punctured or uncapped. The maximum value of brood partially removed was reached at $10 \mathrm{~h}$; it continued until $48 \mathrm{~h}$ after perforation. It was observed that the frequency of brood partially removed was inversely proportional to hygienic behavior (Figures 2 and 3).

\begin{tabular}{|c|c|c|c|c|c|c|c|c|c|c|c|c|c|c|}
\hline & \multirow[t]{2}{*}{ Characters of HB } & \multicolumn{13}{|c|}{ Time of the observations after the perforation } \\
\hline & & $0 \mathrm{~h}$ & $2 \mathrm{~h}$ & $4 \mathrm{~h}$ & $6 \mathrm{~h}$ & $8 \mathrm{~h}$ & $10 \mathrm{~h}$ & $24 \mathrm{~h}$ & $26 \mathrm{~h}$ & $28 \mathrm{~h}$ & $30 \mathrm{~h}$ & $32 \mathrm{~h}$ & $34 \mathrm{~h}$ & $48 \mathrm{~h}$ \\
\hline Hive & $\mathrm{CC}$ & 94.300 & 63.15 & 44.45 & 36.10 & 30.10 & 27.48 & 11.75 & 11.15 & 11.50 & 10.85 & 10.35 & 9.98 & 6.93 \\
\hline \multirow[t]{7}{*}{88} & EC & 5.75 & 6.00 & 7.63 & 11.78 & 21.88 & 24.63 & 71.08 & 74.70 & 75.70 & 77.85 & 79.73 & 81.48 & 90.78 \\
\hline & $\mathrm{PC}$ & 0.00 & 25.48 & 29.60 & 25.60 & 24.13 & 19.60 & 2.38 & 1.88 & 1.50 & 0.75 & 0.75 & 1.00 & 0.00 \\
\hline & UC & 0.00 & 5.10 & 8.55 & 10.73 & 5.40 & 5.63 & 1.63 & 1.88 & 0.63 & 1.25 & 0.38 & 0.25 & 0.00 \\
\hline & $\begin{array}{c}\text { Association of } \\
\mathrm{PC}+\mathrm{UC}+\mathrm{BPR}\end{array}$ & 0.00 & 0.25 & 8.28 & 15.80 & 18.53 & 22.63 & 13.13 & 10.38 & 10.65 & 9.25 & 8.78 & 7.28 & 2.25 \\
\hline & BPR & 0.00 & 30.83 & 46.43 & 52.13 & 48.05 & 47.85 & 17.13 & 14.13 & 12.78 & 11.25 & 9.90 & 8.53 & 2.25 \\
\hline & $\begin{array}{l}\text { Mean of the } \\
\text { correction factor }(\mathrm{Z})\end{array}$ & 0.00 & 0.00 & 0.00 & 0.00 & 0.00 & 0.38 & 1.31 & 1.96 & 2.23 & 2.23 & 2.23 & 2.23 & 2.79 \\
\hline & Mean HB & 0.00 & 0.28 & 2.02 & 6.47 & 17.21 & 19.77 & 68.36 & 71.55 & 72.36 & 74.60 & 76.52 & 78.35 & 87.50 \\
\hline \multirow{8}{*}{$\begin{array}{l}\text { Hive } \\
150\end{array}$} & $\mathrm{CC}$ & 86.33 & 51.08 & 28.75 & 24.83 & 22.03 & 19.75 & 12.85 & 12.38 & 10.80 & 10.68 & 9.85 & 9.55 & 7.38 \\
\hline & EC & 13.68 & 13.68 & 15.58 & 19.58 & 20.83 & 23.48 & 64.20 & 68.53 & 74.03 & 77.05 & 79.75 & 82.18 & 89.00 \\
\hline & $\mathrm{PC}$ & 0.00 & 11.80 & 19.98 & 12.73 & 10.73 & 10.75 & 5.13 & 3.75 & 2.50 & 2.63 & 2.00 & 2.25 & 1.38 \\
\hline & $\mathrm{UC}$ & 0.00 & 22.93 & 25.13 & 21.75 & 19.03 & 15.40 & 1.50 & 0.75 & 0.75 & 0.50 & 0.25 & 0.25 & 0.50 \\
\hline & $\begin{array}{c}\text { Association of } \\
P C+U C+B P R\end{array}$ & 0.00 & 0.50 & 10.53 & 20.38 & 27.38 & 30.63 & 16.30 & 14.63 & 11.90 & 8.88 & 8.13 & 5.75 & 1.75 \\
\hline & $\mathrm{BPR}$ & 0.00 & 54.23 & 68.18 & 71.10 & 73.70 & 73.98 & 30.05 & 25.65 & 20.40 & 16.25 & 13.88 & 10.25 & 3.63 \\
\hline & $\begin{array}{l}\text { Mean of the } \\
\text { correction factor }(\mathrm{Z})\end{array}$ & 0.00 & 0.00 & 0.00 & 1.05 & 1.50 & 1.94 & 2.25 & 2.25 & 2.25 & 2.63 & 2.63 & 3.95 & 3.95 \\
\hline & Mean HB & 0.00 & 0.00 & 2.35 & 5.39 & 10.14 & 12.78 & 57.25 & 60.05 & 67.50 & 69.67 & 72.82 & 74.40 & 82.30 \\
\hline \multirow{8}{*}{$\begin{array}{l}\text { Hive } \\
236\end{array}$} & $\mathrm{CC}$ & 92.55 & 49.20 & 34.15 & 32.90 & 25.15 & 22.78 & 9.20 & 8.53 & 7.98 & 7.80 & 7.65 & 7.13 & 7.13 \\
\hline & $\mathrm{EC}$ & 7.43 & 8.28 & 9.83 & 11.83 & 20.98 & 26.83 & 80.75 & 82.75 & 84.35 & 88.45 & 89.10 & 90.63 & 92.88 \\
\hline & $\mathrm{PC}$ & 0.00 & 29.43 & 33.73 & 30.70 & 20.55 & 16.70 & 2.00 & 1.75 & 1.25 & 0.50 & 0.50 & 0.25 & 0.00 \\
\hline & $\mathrm{UC}$ & 0.00 & 11.10 & 14.33 & 11.55 & 9.10 & 10.25 & 0.50 & 0.75 & 0.25 & 0.00 & 0.00 & 0.25 & 0.00 \\
\hline & $\begin{array}{c}\text { Association of } \\
\mathrm{PC}+\mathrm{UC}+\mathrm{BPR}\end{array}$ & 0.00 & 1.95 & 7.98 & 13.00 & 21.70 & 23.45 & 7.53 & 6.70 & 6.18 & 3.25 & 2.75 & 1.75 & 0.00 \\
\hline & $\mathrm{BPR}$ & 0.00 & 42.48 & 56.03 & 55.25 & 51.35 & 50.40 & 10.03 & 9.20 & 7.68 & 3.75 & 3.25 & 2.25 & 0.00 \\
\hline & $\begin{array}{l}\text { Mean of the } \\
\text { correction factor }(Z)\end{array}$ & 0.00 & 0.00 & 0.00 & 0.00 & 0.00 & 0.00 & 0.79 & 0.79 & 0.79 & 1.04 & 1.04 & 1.04 & 1.04 \\
\hline & Mean HB & 0.00 & 0.95 & 2.65 & 4.84 & 17.35 & 21.02 & 78.99 & 80.94 & 82.82 & 86.74 & 87.49 & 89.19 & 91.49 \\
\hline Hive & $\mathrm{CC}$ & 95.60 & 50.67 & 38.13 & 29.53 & 22.73 & 20.47 & 11.60 & 10.90 & 8.83 & 9.33 & 9.33 & 9.00 & 6.67 \\
\hline \multirow[t]{7}{*}{301} & EC & 4.07 & 6.60 & 6.60 & 8.73 & 16.97 & 21.03 & 69.87 & 71.93 & 73.27 & 77.93 & 81.67 & 83.67 & 91.67 \\
\hline & $\mathrm{PC}$ & 0.00 & 38.67 & 47.17 & 44.73 & 38.40 & 33.00 & 7.00 & 6.17 & 6.70 & 4.33 & 3.33 & 3.33 & 0.67 \\
\hline & $\mathrm{UC}$ & 0.33 & 3.20 & 5.87 & 7.00 & 7.10 & 7.03 & 4.83 & 3.40 & 2.57 & 2.33 & 2.33 & 1.33 & 1.00 \\
\hline & $\begin{array}{c}\text { Association of } \\
\mathrm{PC}+\mathrm{UC}+\mathrm{BPR}\end{array}$ & 0.00 & 0.87 & 2.23 & 10.00 & 14.80 & 18.30 & 6.70 & 7.60 & 8.63 & 6.07 & 3.33 & 2.67 & 0.00 \\
\hline & BPR & 0.33 & 42.73 & 55.27 & 61.73 & 60.30 & 58.33 & 18.53 & 17.17 & 17.90 & 12.73 & 9.00 & 7.33 & 1.67 \\
\hline & $\begin{array}{l}\text { Mean of the } \\
\text { correction factor }(\mathrm{Z})\end{array}$ & 0.00 & 0.00 & 0.00 & 0.00 & 0.00 & 0.00 & 0.35 & 0.85 & 0.85 & 1.18 & 1.18 & 1.51 & 1.51 \\
\hline & Mean HB & 0.00 & 2.77 & 2.77 & 5.17 & 14.10 & 18.50 & 68.99 & 70.39 & 71.89 & 76.52 & 80.42 & 82.16 & 90.36 \\
\hline
\end{tabular}




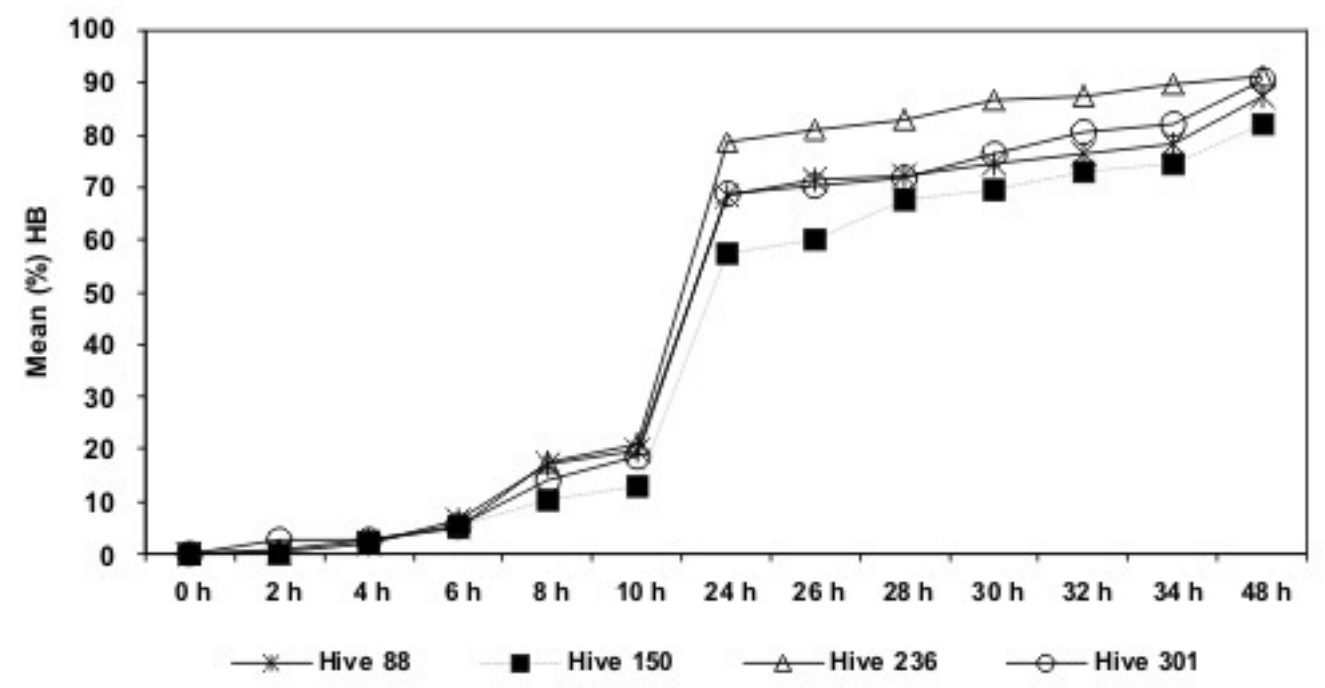

Figure 1. Mean (in \%) of the hygienic behavior (HB) registered in different hours after the perforation of the brood cells of four hives of Carniolan bees (Apis mellifera carnica).

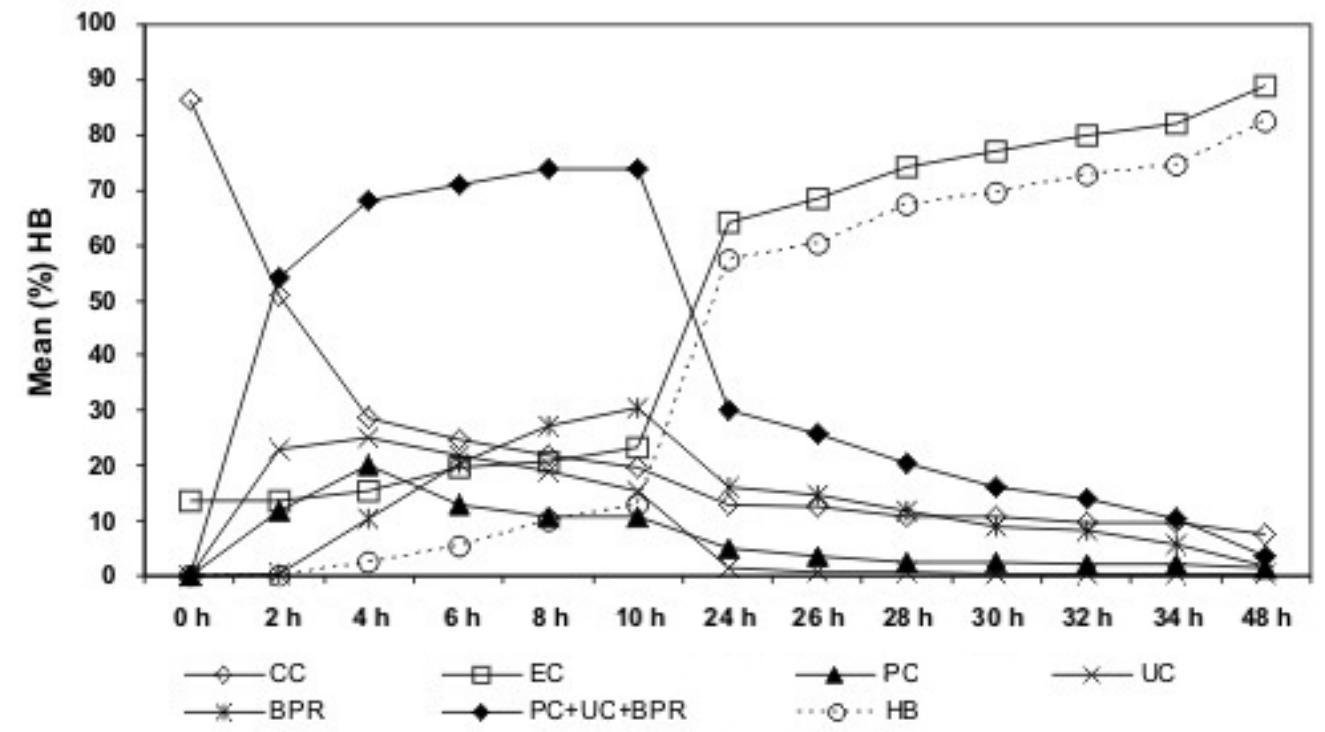

Figure 2. Mean (in \%) of six characters involved in the hygienic behavior (HB) of Carniolan honey bees (Apis mellifera carnica), hive 150 non-hygienic, obtained in different hours after the perforation of the brood cells. Capped cells (CC), empty cells (EC), punctured cells (PC), uncapped cells (UC), association of PC + UC + BPR, brood partially removed (BPR) and $\mathrm{HB}$. 


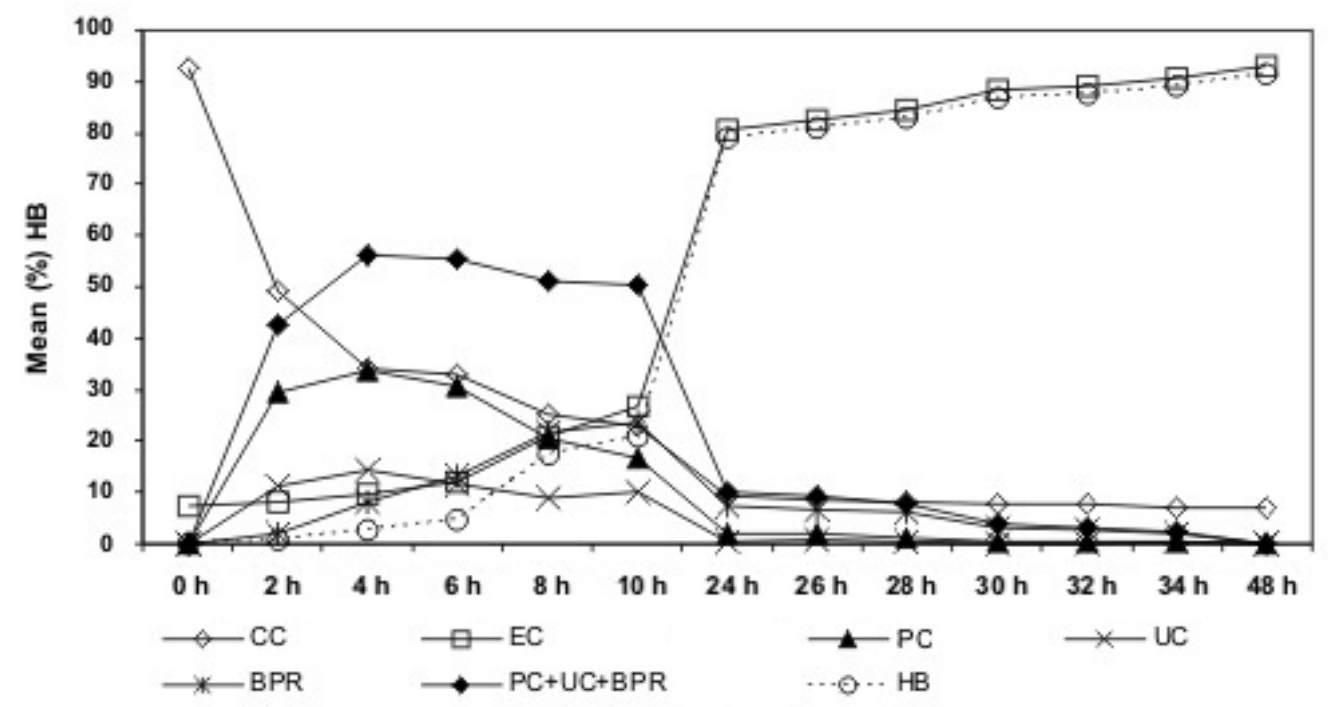

Figure 3. Mean (in \%) of six characters involved in the hygienic behavior (HB) of Carniolan honey bees (Apis mellifera carnica), hive 236 hygienic, obtained in different hours after the perforation of the brood cells. Capped cells (CC), empty cells (EC), punctured cells (PC), uncapped cells (UC), association of PC + UC + BPR, brood partially removed (BPR) and $\mathrm{HB}$.

\section{Series 2. Monitoring of individual brood cells}

The steps or sequences of the hygienic behavior of the honey bees in the hygienic and the non-hygienic colonies were determined by calculating the most frequent order of events (characters) registered in the individual brood cells. The five most frequent sequences for these two colonies were recorded (Table 2 and Figure 4).

Table 2. Sequences of events (characters) or steps of hygienic behavior observed in the individual brood cells monitored in each colony (236 hygienic and 150 non-hygienic).

\begin{tabular}{llc}
\hline Colony & Sequences of characters & Frequency (\%) \\
\hline 236 & $\mathrm{CC} \rightarrow \mathrm{PC} \rightarrow \mathrm{UC} \rightarrow \mathrm{BPR} \rightarrow \mathrm{EC}$ & 14 \\
& $\mathrm{CC} \rightarrow \mathrm{PC} \rightarrow \mathrm{BPR} \rightarrow \mathrm{EC}$ & 26 \\
$\mathrm{CC} \rightarrow \mathrm{PC} \rightarrow \mathrm{UC} \rightarrow \mathrm{EC}$ & 9 \\
$\mathrm{CC} \rightarrow \mathrm{PC}+\mathrm{EC}$ & 18 \\
$\mathrm{CC} \rightarrow \mathrm{UC} \rightarrow \mathrm{BPR} \rightarrow \mathrm{EC}$ & 4 \\
& $\mathrm{CC} \rightarrow \mathrm{PC} \rightarrow \mathrm{UC} \rightarrow \mathrm{BPR} \rightarrow \mathrm{EC}$ & 23 \\
& $\mathrm{CC} \rightarrow \mathrm{PC} \rightarrow \mathrm{BPR} \rightarrow \mathrm{EC}$ & 37 \\
$\mathrm{CC} \rightarrow \mathrm{PC} \rightarrow \mathrm{UC} \rightarrow \mathrm{EC}$ & 8 \\
$\mathrm{CC} \rightarrow \mathrm{PC} \rightarrow \mathrm{UC}$ & 5 \\
$\mathrm{CC} \rightarrow \mathrm{UC} \rightarrow \mathrm{BPR} \rightarrow \mathrm{EC}$ & 14 \\
\hline
\end{tabular}

$\overline{\mathrm{CC}}=$ capped cells; $\mathrm{PC}=$ punctured cells; $\mathrm{UC}=$ uncapped cells; $\mathrm{BPR}=$ brood partially removed; $\mathrm{EC}=$ empty cells. 


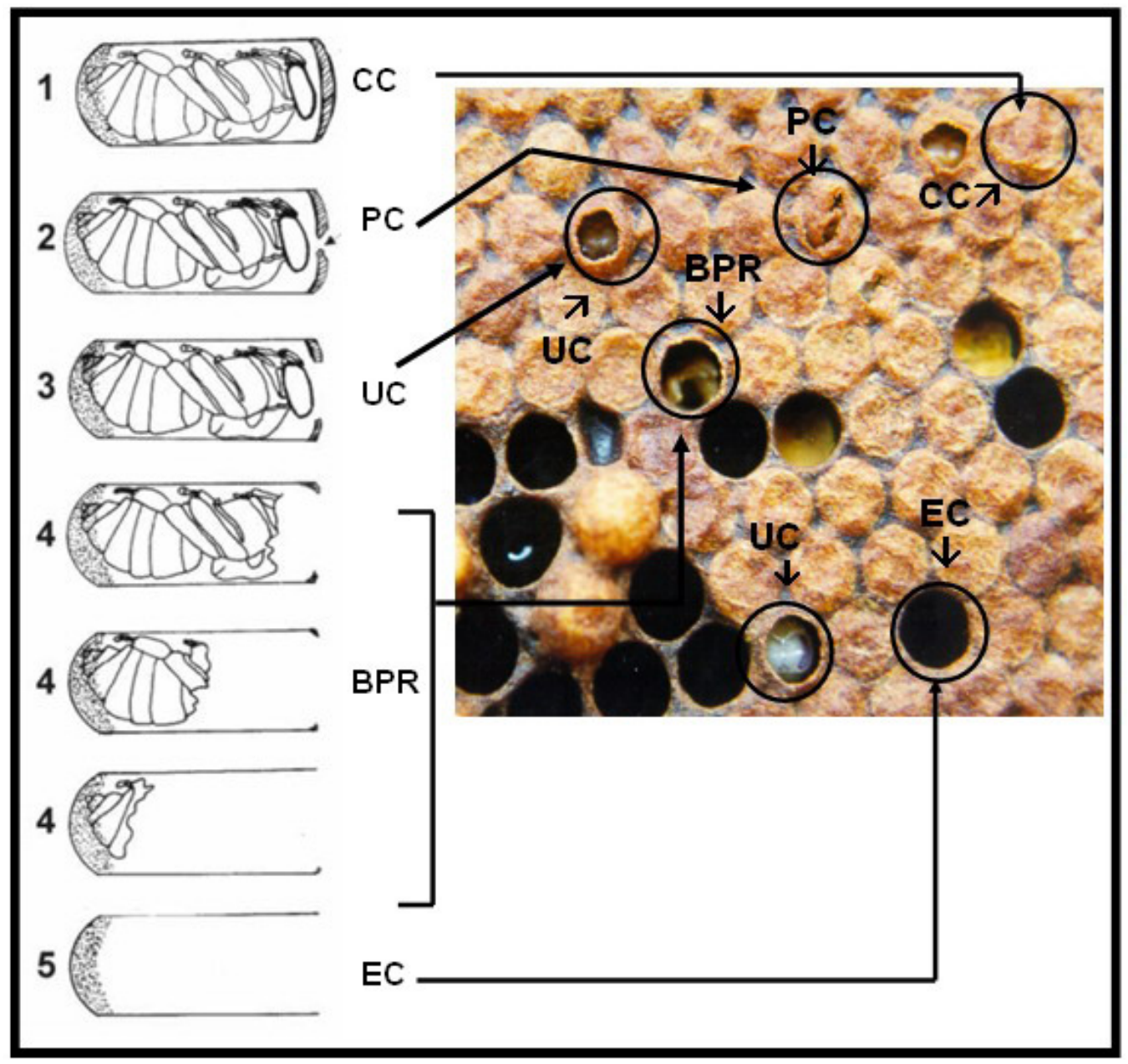

Figure 4. Steps of hygienic behavior: 1. Capped cell (CC), empty cell (EC). 2. Punctured cell (PC). 3. Uncapped cell (UC), association of PC + UC + BPR. 4. Brood partially removed (BPR) and hygienic behavior. 5. Empty cell.

\section{DISCUSSION AND CONCLUSIONS}

We found great variability in the sequence of behaviors of hygienic behavior. Within $2 \mathrm{~h}$ after the cell capping is perforated with a pin, perforating the brood inside, the workers detect the dead or injured pupa and start to make small holes in the brood cell capping. We recommend a 24-h test to evaluate hygienic behavior of a colony and use of a correction factor to account for control removal rates. The most frequent sequence of events (characters) or steps of the hygienic behavior both for the hygienic and non-hygienic colonies was: $\mathrm{CC} \rightarrow \mathrm{PC}$ $\rightarrow \mathrm{BPR} \rightarrow \mathrm{EC}$. This means that the workers start hygienic behavior by puncturing the capped 
brood cell, making small holes in it, followed by uncapping of the brood cell and removal of the brood. However, the brood can be partially or totally removed. Rarely, punctured cell was followed by capped cell. We found that there are normally three main steps involved in hygienic behavior of honey bees after they identify the damaged brood inside the cell; these are puncturing of the capping, uncapping of the brood cell and removal of the brood.

We have observed that normally the workers remove the injured pupae by eating them (cannibalism) instead of simply removing the pupa. However, sometimes they did remove the pupa without eating it. Rarely, we observed punctured capping followed by capped cell. We observed that the higher the frequency of brood partially removed, the less hygienic the colony. Brood partially removed occurred more frequently after punctured capping and less frequently after uncapped cell; we suppose that brood partially removed is a sign of cannibalism. This brood condition was observed more frequently in the non-hygienic colony. It was observed that the puncturing of the brood cells had already started $2 \mathrm{~h}$ after perforation, at a frequency of $42 \%$. Uncapped cell was recorded directly without observing perforated cell only in $2 \%$ of the cells. We concluded that uncapping of the brood cells is preceded by puncturing. Finally, based on our results, we proposed a new hypothesis to explain the genetic control of hygienic behavior in Apis mellifera. Instead of two pairs of genes $(\mathrm{u}=$ uncapping and $\mathrm{r}=$ remover) proposed by Rothenbuhler (1964a,b), our model involves three pairs of recessive genes (u1, u2 and r). In order to uncap the cell the bee should have both $\mathrm{u} 1$ and $\mathrm{u} 2$ genes in homozygosity (u1/u1, u2/ $\mathrm{u} 2)$. Only one $\mathrm{u} 1$ or $\mathrm{u} 2$ gene in homozygosity would determine puncturing ( $\mathrm{u} 1 / \mathrm{u} 1, \mathrm{u} 2 /+$ or $\mathrm{u} 1 /+$, $\mathrm{u} 2 / \mathrm{u} 2$ ); while all three genes in homozygosity would be responsible for uncapping and removal $(\mathrm{u} 1 / \mathrm{u} 1, \mathrm{u} 2 / \mathrm{u} 2, \mathrm{r} / \mathrm{r})$. The sequence of steps would be puncturing and uncapping the capped cells, followed by removal of the brood. This new hypothesis is based on the observations made of individual worker brood cells after pin killing; it needs to be tested with further observations.

\section{ACKNOWLEDGMENTS}

We thank Dr. Peter Rosenkranz, head of the Bee Laboratory of the University of Hohenheim, Stuttgart, Germany, for his support and for laboratory facilities and Prof. Dr. David De Jong (USP, Ribeirão Preto) for the revision of this paper.

\section{REFERENCES}

Gilliam M, Taber S III and Richardson GV (1983). Hygienic behavior of honey bees in relation to chalkbrood disease. Apidologie 14: 29-39.

Gonçalves LS and Kerr WE (1970). Genética, Seleção e Melhoramento. 1. Noções Sobre Genética e Melhoramento em Abelhas. In: Anais do $1^{\circ}$ Congresso Brasileiro de Apicultura, Florianópolis, 8-36.

Gramacho KP and Gonçalves LS (1994). Estudo Comparativo dos Métodos de Congelamento e Perfuração de Crias, para Avaliação do Comportamento Higiênico em Abelhas Africanizadas. In: IV Congresso Latinoiberoamericano de Apicultura e I Expo - Comercial Internacional de Apicultura, Córdoba, Anais, 45.

Gramacho KP and Gonçalves LS (1996). A Comparative Study of Hygienic Behavior in Several Honey Bee Races. In: Proceedings of the 20th International Congress of Entomology, Firenze, 445.

Gramacho KP, Gonçalves LS and Rosenkranz P (1998). Study of the temperature of brood killed by the pin-killing method in worker bees of Apis mellifera carnica. Apiacta 33: 33-41.

Kefuss J, Taber S, van Pouecke J and Rey F (1996). Un método prático para comprobar el comportamiento higiénico. Vida Apicola 76: 26-29.

Message D (1979). Efeito de Condições Ambientais no Comportamento Higiênico em Abelhas Africanizadas Apis mellifera. Master's thesis, Faculdade de Medicina de Ribeirão Preto, USP, Ribeirão Preto. 
Message D and Gonçalves LS (1984a). Efeito das Condições Climáticas e da Colônia no Comportamento Higiênico em Abelhas Apis mellifera (Africanizadas). In: Anais do $5^{\circ}$ Congresso Brasileiro de Apicultura, Viçosa, 140-147.

Message D and Gonçalves LS (1984b). Efeito das Condições do Favo Teste no Comportamento Higiênico em Abelhas Apis mellifera (Africanizadas). In: Anais do $5^{\circ}$ Congresso Brasileiro de Apicultura, Viçosa, 133-139.

Milne CP Jr (1985). Laboratory tests of honey bee hygienic behavior and resistance to European foulbrood. Am. Bee J. 125: $578-580$.

Moretto G (1993). Estudo de Algumas Variáveis Relacionadas a um Mecanismo de Defesa de Operárias de Apis mellifera à Varroatose e à Taxa de Reprodução do Ácaro Varroa jacobsoni. Doctoral thesis, Faculdade de Medicina de Ribeirão Preto, USP, Ribeirão Preto.

Moritz RFA (1988). A reevaluation of the two-locus model for hygienic behavior in honeybees (Apis mellifera L.). $J$. Hered. 79: 257-262.

Newton DC and Ostasiewski NJA (1986). A simplified bioassay for behavioral resistance to American foulbrood in honey bees (Apis mellifera L). Am. Bee J. 126: 278-281.

Park OW, Pellett FC and Paddock FB (1937). Disease resistance and American foulbrood. Am. Bee J. 77: 20-25.

Rothenbuhler WC (1964a). Behaviour genetics of nest cleaning in honey bees. I. Responses of four inbred lines to diseasekilled brood. Anim. Behav. 12: 578-583.

Rothenbuhler WC (1964b). Behaviour genetics of nest cleaning in honey bees. IV. Responses of F1 and backcross generations to disease-killed brood. Am. Zool. 4: 111-123.

Spivak M and Reuter GS (1998). Hygienic honey bees and resistance to varroa and brood diseases. Am. Bee J. 138: 299.

Woodrow AW and Holst EC (1942). The mechanism of colony resistance to American foulbrood. J. Econ. Entomol. 35: 327-330. 